\title{
PENGARUH KEADILAN ORGANISASIONAL PADA MOTIVASI KARYAWAN DAN KOMITMEN ORGANISASIONAL
}

\author{
Wiwiek \\ International Business Management Universitas Ciputra \\ Oliandes Sondakh \\ Business School, Universitas Pelita Harapan Surabaya \\ e-mail: oliandes.sondakh@uph.edu
}

\begin{abstract}
A number of previous studies conducted have shown the influence of employee motivation and company performance. According to the theories of social comparison, motivation is influences employee perceptions of how fairly they are treated. This research study will focus on a traditional family owned company in Indonesia, where the human resource activities that occur in the company are still based on the principle of kinship. Based on the results of research conducted at UD. X, it can be concluded that Distributive and Interactional Justice has a positive and significant impact on employee motivation, while only Distributive Justice has a positive and significant effect on organizational commitment. Employee Motivation has proven to positively and significantly affect Organizational Commitment. The interesting issues will be further discussed.
\end{abstract}

Keywords: Distributive Justice, Prosedural Justice, Interactional Justice, Employee motivation, Organizational Commitment

\begin{abstract}
Abstrak
Sejumlah penelitian yang pernah dilakukan sebelumnya telah membuktikan pengaruh dari motivasi kerja karyawan terhadap kinerja perusahaan. Menurut teori-teori perbandingan sosial, motivasi sangat dipengaruhi persepsi karyawan terhadap seberapa adil mereka diperlakukan. Penelitian ini mengambil obyek salah satu perusahaan keluarga tradisional di Indonesia, dimana kegiatan sumber daya manusia yang terjadi di dalam perusahaan masih berlandaskan asas kekeluargaan. Berdasarkan hasil penelitian yang dilakukan di UD. X, maka dapat diambil simpulan bahwa Keadilan Distributif dan Interaksional berpengaruh positif dan signifikan terhadap Motivasi Karyawan, sementara hanya Keadilan Distributif yang berpengaruh positif dan signifikan terhadap komitmen organisasional. Motivasi Karyawan terbukti mampu secara positif dan signifikan mempengaruhi Komitmen Organisasional. Isu-isu menarik lainnya juga akan didiskusikan lebih lanjut.
\end{abstract}

Kata Kunci: Keadilan Distributif, Keadilan Prosedural, Keadilan Interaksional, Motivasi Karyawan, Komitmen Organisasional

\section{LATAR BELAKANG MASALAH}

Di tengah sengitnya persaingan di era globalisasi saat ini, perusahaan dituntut untuk senangtiasa bekerja keras tidak hanya dalam mencapai efisiensi dan efektivitas dalam kegiatan operasional perusahaan tetapi juga dalam hal sumber daya manusia (Dessler \& Tan, 2009). Hal ini terutama karena perusahaan saat ini sudah menyadari bahwa karyawan merupakan aset yang paling penting dan memiliki peranan besar dalam mencapai keberhasilan perusahaan (Robbins \& Coulter, 2009). Sejumlah penelitian yang pernah dilakukan sebelumnya telah membuktikan pengaruh dari motivasi kerja karyawan terhadap kinerja perusahaan. Motivasi yang tinggi dapat menyebabkan kepuasan kerja dan komitmen terhadap organisasi (Karsli $\&$ Iskender, 2009). Motivasi juga sangat mempengaruhi turnover intention (Dysvik \& Kuvaas, 2009). Karena itu penting bagi per- 
usahaan untuk mengetahui bagaimana memotivasi karyawan (Robbins \& Coulter, 2009). Memotivasi karyawan bukanlah pekerjaan yang mudah, perlu adanya usaha yang keras dan pengetahuan yang mendalam sehingga karyawan bersedia bergabung dengan perusahaan, memberikan kinerja yang baik, dan mempunyai kmitmen terhadap perusahaan (Dessler \& Tan, 2009).

Ivancevich (2007) menyatakan bahwa menurut teori-teori perbandingan sosial, motivasi sangat dipengaruhi persepsi karyawan terhadap seberapa adil mereka diperlakukan. Berdasarkan teori pertukaran (exchange theory) dan teori keadilan (equity theory), tingkat keadilan dan ketidakadilan yang dirasakan karyawan di lingkungan kerja jika dibandingkan dengan karyawan lain menjadi penentu utama produktivitas dan kepuasan karyawan. Teori keadilan adalah ketika karyawan merasa diperlakukan secara adil akan lebih termotivasi dalam bekerja (William, 2007). Lebih lanjut menurut Dessler dan Tan (2009) dalam teori keadilan mengatakan bahwa karyawan mencari keadilan di dalam pekerjaannya. Karyawan menginginkan adanya keadilan antara kontribusi yang telah diberikan kepada organisasi dengan hasil yang didapatkan. Namun, tidak hanya berhenti pada hasil yang diperoleh, teori keadilan lebih lanjut menjelaskan bahwa tidak hanya membandingkan antara kontribusi (input) dan hasil (outcomes), karyawan juga cenderung membandingkan dirinya dengan karyawan lain yang memiliki karakteristik lain yang sama atau yang lebih dikenal dengan istilah referent (Williams, 2007).

Berdasarkan proses teori keadilan, karyawan akan membandingkan outcomes yang diterima dari organisasi dengan input yang diberikan kepada organisasi. Setelah dilakukan perbandingan internal antara input dan outcomes, karyawan akan melakukan perbandingan eksternal. Karyawan akan membandingkan hasil perbandingan input dan outcomes internal dengan hasil perbandingan input dan outcomes dari referents. Ketika karyawan mendapati hasil perbandingan dengan referent sama, maka akan disimpulkan bahwa mereka telah mendapat perlakuan yang adil. Namun jika hasilnya tidak sama, maka karyawan akan menyimpulkan bahwa karyawan telah diperlakukan tidak adil (Williams, 2007). Ketika karyawan merasa diperlakukan tidak adil, karyawan akan berusaha untuk merubah kualitas dan kuantitas input karyawan, yang pada akhirnya berpengaruh terhadap kinerja perusahaan (Ivancevich, 2007).

Secara umum, fenomena yang terjadi karyawan lebih cenderung peduli terhadap keadilan akan outcomes yang diperoleh dibandingkan level pasti outcomes yang diperoleh, namun dalam perusahaan keluarga, konsep keadilan akan lebih rumit, karena tidak hanya membandingkan outcomes yang diperoleh, tetapi juga membandingkan input/outcome mereka dengan inputs/outcomes individu yang lain dalam kerangka acuan mereka. Contohnya dengan anggota keluarga pemilik yang juga bekerja di perusahaan tersebut. Jika hasilnya tidak sama, maka akan timbul persepsi ketidakadilan (Sieger, Fabian, \& Urs, 2011; Sia, Bhardwaj, \& Sahoo, 2013).

Penelitian ini mengambil obyek salah satu perusahaan keluarga tradisional di Indonesia, dimana kegiatan sumber daya manusia yang terjadi di dalam perusahaan masih berlandaskan asas kekeluargaan. Hasil penelitian ini dapat digunakan sebagai acuan bagaimana persepsi akan keadilan yang diterima karyawan dapat mempengaruhi motivasi karyawan dan komitmen organisasional yang pada akhirnya akan berdampak pada kinerja perusahaan.

\section{TINJAUAN PUSTAKA}

\section{Komitmen Organisasional}

Meyer dan Allen (1997) mendefinisikan kmitmen organisasi sebagai kemauan atau keinginan yang kuat dari anggota organisasi untuk tetap berada, bekerja, dan memiliki keterikatan terhadap organisasi. Dengan demikian, komitmen organisasi menurut Gibson, Ivancevich, Donnelly, \& Konopaske (2009) dapat didefinisikan sebagai identifikasi rasa, keterlibatan, dan kesetiaan yang ditampakkan oleh karyawan terhadap organisasi atau unit organisasi. Komitmen organisasi yang kuat ditunjukkan dalam sikap penerimaan, dan keyakinan yang kuat terhadap nilai-nilai dan tujuan organisasi, serta adanya dorongan yang kuat untuk mempertahankan keanggotaan dalam organisasi demi tercapainya tujuan organisasi. Dengan demikian, komitmen organisasi dapat dinyatakan sebagai seberapa jauh seorang karyawan mengidentifikasikan dirinya dan ke- 
terlibatannya terhadap organisasi (Vandenberg \& Lance, 1992).

Komitmen organisasi yang tinggi mencerminkan keberpihakan individu yang tinggi terhadap organisasi. Cobb, Folger, dan Wooten (1995) menunjukkan bahwa ketika para karyawan diperlakukan adil, mereka akan mempunyai sikap dan perilaku yang dibutuhkan untuk keberhasilan perubahan organisasi bahkan dalam kondisi sulit sekalipun (Jin, 2006). Sebaliknya, ketika keputusan organisasi dan tindakan manajerial dianggap tidak adil maka karyawan akan merasa marah dan menolak upaya perubahan untuk perbaikan organisasi (Chao, Ya-Ru, \& Xin, 2004).

Pandangan lain dikemukakan oleh Thibaut dan Walker (1975) yang menyatakan bahwa penilaian seseorang mengenai keadilan tidak hanya dipengaruhi oleh apa yang mereka terima sebagai akibat dari keputusan tertentu, tetapi juga pada proses atau bagaimana keputusan tersebut dibuat. Greenberg (1990) menyatakan bahwa semakin tinggi karyawan mempersepsikan keadilan suatu kebijakan ataupun praktek manajemen maka berdampak pada peningkatan kepuasan kerja dan komitmen organisasi, demikian juga sebaliknya.

\section{Motivasi}

Motivasi merupakan faktor kunci untuk membuat karyawan bersedia memberikan sumbangsihnya bagi perusahaan (Hicks \& Gullet, 1981 dalam Karsli \& Iskender, 2009). Lebih lanjut, Karsli dan Iskender (2009) menyatakan bahwa motivasi memiliki karakter yang dinamis karena tergantung pada motif dan kebutuhan pribadi. Kadang individu termotivasi secara positif apabila apa yang diharapkannya tercapai, demikian pula sebaliknya, apabila apa yang individu harapkan dan butuhkan tidak tercapai akan timbul motivasi negatif, sehingga dengan demikian dapat disimpulkan bahwa kedua hal ini dapat mempengaruhi produktivitas individu. Yang harus disadari, banyak orang salah memandang motivasi sebagai suatu ciri individu, artinya seseorang akan termotivasi karena suatu hal tertentu dan yang lainnya tidak (Robbins \& Coulter, 2009). Namun, Robbins dan Coulter (2009) mengingatkan bahwa motivasi adalah proses di mana usaha seseorang diberi energi, diarahkan, dan dipertahankan untuk mencapai sebuah tujuan. Elemen energi dalam pengertian tersebut merupakan sebuah ukuran untuk penggerak motivasi. Seorang yang termotivasi akan bekerja keras dan memberikan usaha yang maksimal. Seberapa besar usaha tersebut perlu diperhatikan. Usaha yang besar tidaklah perlu jika tidak berdampak pada pencapaian tujuan perusahaan. Usaha yang menguntungkan perusahaan merupakan usaha yang diinginkan perusahaan dari karyawannya. Motivasi dalam hal ini mencakup dimensi kegigihan. Perusahaan ingin karyawan memiliki ketekunan dalam memberikan usaha yang besar untuk mencapai tujuan perusahaan.

\section{Keadilan Organisasional}

Sejarah keadilan organisasional berawal dari teori keadilan yang menyatakan bahwa orang membandingkan rasio antara hasil dari pekerjaan yang mereka lakukan, misalnya imbalan dan promosi, dengan input yang mereka berikan dibandingkan rasio yang sama dari orang lain (Adams, 1963). Greenberg (1990) selanjutnya menjelaskan bahwa teori keadilan Adams dilengkapi dengan penelitianpenelitian lanjutan yang terkait dengan alokasi imbalan, merujuk pada konsep yang saat ini dikenal dengan istilah keadilan distributif.

Robbins dan Judge (2008) mendefinisikan keadilan distributif sebagai keadilan atas jumlah dan penghargaan yang dirasakan diantara individu-individu. Secara lebih spesifik, Noe, Hollenbeck, Gerhart, \& Wright, 2011 mendefinisikan keadilan distributif sebagai penilaian yang dibuat oleh individu terkait dengan jumlah imbalan yang diterimanya dibandingkan dengan imbalan yang diterima orang lain yang menjadi acuannya. Lebih lanjut dalam keadilan organisasional tidak hanya dikenal konsep keadilan distributif, tetapi juga dikenal konsep keadilan prosedural dan keadilan interaksional.

Keadilan prosedural didefinisikan sebagai keadilan yang dirasakan individu berdasarkan proses yang digunakan untuk menentukan distribusi dalam jumlah dan penghargaaan (Robbins \& Judge, 2008; Chen, Friedman, Yu, \& Sun, 2011). Sehingga dapat disimpulkan bahwa keadilan prosedural merupakan konsep keadilan yang berfokus pada metode yang digunakan untuk menentukan imbalan yang diterima (Noe et al., 2011; Loi, Lam, \& Chan, 2012). 
Aspek terakhir dari keadilan organisasional adalah keadilan interaksional dan mungkin yang paling sederhana diantara ketiga aspek ini. Robbins dan Judge (2008) mendefinisikan keadilan interaksional sebagai persepsi individu tentang tingkat sampai dimana seorang karyawan diperlakukan dengan penuh martabat, perhatian, dan rasa hormat. Greenberg (1987) menyatakan bahwa terdapat dua aspek dalam keadilan interaksional, yaitu informasional dan interpersonal. Keadilan informasional merupakan persepsi individu tentang keadilan informasi yang digunakan sebagai dasar pembuatan keputusan, sedangkan keadilan interpersonal merupakan persepsi individu tentang keadilan akan perlakuan yang diterimanya (He, Zhu, \& Zheng, 2014). Sehingga seluruh hipotesis dinyatakan sebagai berikut:

H1: keadilan distributif berpengaruh signifikan pada motivasi karyawan,

$\mathrm{H} 2$ : keadilan prosedural berpengaruh signifikan pada motivasi karyawan,

H3: keadilan interaksional berpengaruh signifikan pada motivasi karyawan,

H4: keadilan distributif berpengaruh signifikan pada komitmen organisasional,

H5: keadilan prosedural berpengaruh signifikan pada komitmen organisasional,

H6: keadilan interaksional berpengaruh signifikan pada komitmen organisasional,

H7: motivasi karyawan berpengaruh signifikan pada komitmen organisasional.

\section{METODE PENELITIAN DAN ANALISIS}

Penelitian ini merupakan penelitian kuantitatif, yang bertujuan untuk menguji teori-teori tertentu dengan cara meneliti hubungan antar variable (Noor, 2011). Data dalam penelitian ini dikumpulkan melalui kuesioner, dengan menggunakan lima skala likert. Kuisioner disebar ke seluruh karyawan yang berjumlah 40 responden.

Data yang baik adalah data yang telah teruji keabsahannya, kerena itu data yang ada terlebih dahulu sebaiknya diuji validitas dan reliabilitasnya. Validitas menyatakan keakuratan kuesioner dalam mewakili konsep, sedangkan Reliabilitas menyatakan kekonsistenan butir pertanyaan dari kuesioner, sedangkan (Zikmund, Babin, Carr, \& Griffin, 2010). Dalam penelitian ini, uji validitas dilakukan dengan menggunakan perbandingan antara rhitung dengan r-tabel, sedangkan uji reliabilitas dilakukan dengan menggunakan Alpha Cronbach. Suatu variabel dikatakan valid apabila r-hitung yang diperoleh lebih besar dari rtabel yang disyaratkan, sedangkan suatu variabel dikatakan reliabel apabila memiliki nilai alpha cronbach lebih dari 0,70 (Ghozali, 2012).

Lebih lanjut, Santoso (2009) menyatakan bahwa sebuah model regresi yang baik adalah model yang memiliki kesalahan peramalan yang seminimal mungkin. Oleh karena itu, sebelum dilakukan uji regresi, model yang ada harus memenuhi beberapa asumsi yang biasanya disebut dengan asumsi klasik. Terhadap beberapa uji asumsi klasik yang umum dilakukan, yaitu: (1) Uji normalitas yang bertujuan untuk mengetahui apakah residual yang dihasilkan berdistribusi secara normal atau tidak. Dalam penelitian ini, uji normalitas dilakukan dengan melihat grafik histogram dan normal probability plot. Apabila pada grafik histogram mengikuti pola garis lonceng, dan sebaran normal probability plot mengikuti pola garis lurus diagonal, maka dapat disimpulkan bahwa uji normalitas dipenuhi (Ghozali, 2012); (2) Uji heteroskedastisitas yang bertujuan untuk menguji adanya ketidaksamaan varians dari residual satu pengamatan ke pengamatan lain. Apabila varians residual pengamatan satu dengan yang lain sama, maka disebut homokedastisitas atau tidak terjadi heteroskedastisitas. Model yang baik tidak terjadi heteroskedastisitas (Ghozali, 2012). Uji heteroskedastisitas dapat dilakukan dengan melihat grafik plot antara ZPRED dengan SRESID. Apabila titiktitik pada plot menyebar, maka tidak terjadi heteroskedastisitas; (3) Uji multikolinearitas yang bertujuan untuk menguji ada tidaknya hubungan antara variabel bebas dalam model. Model yang baik tidak menunjukkan adanya gejala multikolinearitas antar variabel bebasnya (Ghozali, 2012). Dalam penelitian ini, uji multikolinearitas diketahui dengan melihat nilai VIF (Variance Inflation Factor). Apabila nilai $\mathrm{VIF}<10$, maka dianggap tidak terjadi multikolinearitas.

Setelah data yang diperoleh telah teruji keabsahannya dan diyakini memiliki kesalahan peramalan yang seminimal mungkin, maka selanjutnya dilakukan uji regresi, yang bertujuan untuk mengetahu pengaruhi dari variabel bebas ke variabel terikat. 


\section{Hasil Analisis}

Uji validitas dilakukan kepada keseluruhan sampel yang berjumlah 40 orang. r-tabel dalam penelitian ini adalah sebesar 0,312 $(\mathrm{n}=40, \alpha=$ $5 \%$ ). Hasil uji validitas menunjukkan bahwa semua indikator dari tiap variabel adalah valid, karena memiliki rhitung yang lebih besar dari rtabel, sehingga dapat dilakukan analisis selanjutnya. Tahap selanjutnya adalah melakukan uji reliabilitas. Hasil uji reliabilitas menunjukkan bahwa nilai Alpha Cronbach tiap variabel memiliki nilai lebih dari 0,60 yang berarti reliabel, sehingga dapat dilakukan analisis asumsi klasik.

Uji normalitas dilakukan untuk mengetahui apakah residual berdistribusi normal atau tidak. Berdasarkan hasil uji normalitas diperoleh hasil bahwa grafik histogram mengikuti pola garis lonceng, dan sebaran titik-titik pada normal probability plot mengikuti pola garis lurus diagonal, maka dapat disimpulkan bahwa uji normalitas dipenuhi. Uji heterokedastisitas dilakukan untuk menguji apakah ada ketidaksamaan varians dari residual satu pengamatan ke pengamatan lain. Berdasarkan hasil uji heterokedastisitas diperoleh hasil bahwa titik-titik pada grafik plot antara ZPRED dengan SRESID menyebar secara acak baik di bawah maupun di atas sumbu Y, sehingga dapat disimpulkan tidak terjadi heteroskedastisitas. Variabel keadilan distributif, prosedural dan interaksional memiliki nilai VIF yang kurang dari 10 dan variance lebih dari 0 sehingga dapat dikatakan tidak terjadi multikolinearitas sehingga antar variabel independen dalam penelitian ini.

Hipotesis pertama (H1) yang diuji adalah keadilan distributif berpengaruh terhadap motivasi karyawan. Hipotesis ini diuji dengan menggunakan uji-t. Hasil perhitungan menunjukkan koefisien sebesar 0,526 dengan thitung sebesar 4,272 dan signifikansi 0,000; artinya keadilan distributif berpengaruh terhadap motivasi karyawan (H1 terbukti).

Hipotesis kedua $(\mathrm{H} 2)$ yang diuji adalah keadilan prosedural berpengaruh terhadap motivasi karyawan. Hipotesis ini diuji dengan menggunakan uji-t. Hasil perhitungan menunjukkan koefisien sebesar - 0,166 dengan t-hitung sebesar - 0,960 dan signifikansi 0,343; artinya keadilan prosedural tidak berpengaruh terhadap motivasi karyawan (H2 tidak terbukti).
Hipotesis ketiga (H3) yang diuji adalah keadilan interaksional berpengaruh terhadap motivasi karyawan. Hipotesis ini diuji dengan menggunakan uji-t. Hasil perhitungan menunjukkan koefisien sebesar 0,249 dengan thitung sebesar 2,359 dan signifikansi 0,024; artinya keadilan interaksional berpengaruh terhadap motivasi karyawan (H3 terbukti).

Persamaan yang dapat dibentuk adalah sebagai berikut:

MK $=1,287+0,526$ KD - 0,166 KP + 0,249 KI

Dimana:

$\mathrm{M}=$ Motivasi Karyawan

$\mathrm{KD}=$ Keadilan Distributif

$\mathrm{KP}=$ Keadilan Prosedural

$\mathrm{KI}=$ Keadilan Interaksional

Untuk melihat kecocokan model, maka dilihat pada hasil perhitungan koefisien determinasi (R2). Hasil perhitungan menunjukkan nilai koefisien determinasi adalah sebesar 0,691. Artinya adalah motivasi karyawan ditentukan oleh keadilan distributif, prosedural, dan interaksional adalah sebesar $69,1 \%$; sedangkan sisa $30,9 \%$ ditentukan oleh faktor-faktor lain yang tidak diteliti dalam penelitian ini.

Hipotesis keempat (H4) yang diuji adalah keadilan distributif berpengaruh terhadap komitmen organisasional. Hipotesis ini diuji dengan menggunakan uji-t. Hasil perhitungan menunjukkan koefisien sebesar 0,666 dengan t-hitung sebesar 4,626 dan signifikansi 0,000; artinya keadilan distributif berpengaruh terhadap motivasi karyawan (H4 terbukti).

Hipotesis kelima (H5) yang diuji adalah keadilan prosedural berpengaruh terhadap komitment organisasional. Hipotesis ini diuji dengan menggunakan uji-t. Hasil perhitungan menunjukkan koefisien sebesar 0,107 dengan thitung sebesar 0,530 dan signifikansi 0,599; artinya keadilan prosedural tidak berpengaruh terhadap komitmen organisasional (H5 tidak terbukti).

Hipotesis keenam (H6) yang diuji adalah keadilan interaksional berpengaruh terhadap motivasi karyawan. Hipotesis ini diuji dengan menggunakan uji-t. Hasil perhitungan menunjukkan koefisien sebesar 0,232 dengan thitung sebesar 1,883 dan signifikansi 0,068; artinya keadilan interaksional tidak berpengaruh terhadap motivasi karyawan (H6 tidak terbukti). 
Persamaan yang dapat dibentuk adalah sebagai berikut:

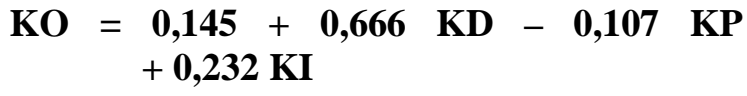

Dimana:

$\mathrm{KO}=$ Komitmen Organisasional

$\mathrm{KD}=$ Keadilan Distributif

$\mathrm{KP}=$ Keadilan Prosedural

$\mathrm{KI}=$ Keadilan Interaksional

Untuk melihat kecocokan model, maka dilihat pada hasil perhitungan koefisien determinasi (R2). Hasil perhitungan menunjukkan nilai koefisien determinasi adalah sebesar 0,740. Artinya adalah motivasi karyawan ditentukan oleh keadilan distributif, prosedural, dan interaksional adalah sebesar 74\%; sedangkan sisa 26\% ditentukan oleh faktor-faktor lain yang tidak diteliti dalam penelitian ini.

Hipotesis ketujuh (H7) yang diuji adalah motivasi karyawan berpengaruh terhadap komitmen organisasional. Hipotesis ini diuji dengan menggunakan uji-t. Hasil perhitungan menunjukkan koefisien sebesar 0,739 dengan t-hitung sebesar 4,478 dan signifikansi 0,000 ; artinya keadilan motivasi karyawan berpengaruh terhadap komitmen organisasional (H7 terbukti). sebagai berikut:

Persamaan yang dapat dibentuk adalah

$$
\text { KO = 1,144 + 0,739 MK }
$$

Dimana:

$\mathrm{KO}=$ Komitmen Organisasional

MK = Motivasi Karyawan

Untuk melihat kecocokan model, maka dilihat pada hasil perhitungan koefisien determinasi (R2). Hasil perhitungan menunjukkan nilai koefisien determinasi adalah sebesar 0,588 . Artinya adalah motivasi karyawan ditentukan oleh keadilan distributif, prosedural, dan interaksional adalah sebesar 58,8\%; sedangkan sisa $41,2 \%$ ditentukan oleh faktorfaktor lain yang tidak diteliti dalam penelitian ini.

\section{PEMBAHASAN}

Hasil uji hipotesis pertama, kedua dan ketiga menunjukkan bahwa hanya keadilan distributif dan interaksional yang memiliki pengaruh signifikan terhadap motivasi karyawan, sedangkan keadilan prosedural memiliki pengaruh negatif dan tidak signifikan terhadap motivasi karyawan. Hal ini berarti bahwa penerapan keadilan di UD. X yang cukup adil sehingga membuat karyawan mempunyai cukup motivasi untuk bekerja di perusahaan. Namun, karena kebanyakan karyawan sudah bekerja cukup lama di UD. X dan mempunyai usia yang cukup lanjut, jadi ketika ada karyawan baru yang masuk dengan tingkat pendidikan yang lebih tinggi dan mendapat tingkat imbalan yang lebih tinggi, hal tersebut menurunkan motivasi karyawan lain yang lebih lama bekerja namun mempunyai tingkat pendidikan yang lebih rendah, sehingga keadilan prosedural yang ditetapkan perusahaan tidak mampu memotivasi dan bahkan menurunkan motivasi karyawan.

Hasil uji hipotesis keempat, kelima dan keenam menunjukkan bahwa hanya keadilan distributif yang memiliki pengaruh signifikan terhadap komitmen organisasional, sedangkan keadilan prosedural dan interaksional memiliki pengaruh yang tidak signifikan terhadap komitmen organisasional walaupun arah pengaruhnya masih positif. Hal ini disebabkan karena kebanyakan karyawan sudah bekerja cukup lama di UD. $\mathrm{X}$ dan mempunyai usia yang cukup lanjut, sehingga agak kesulitan untuk berganti pekerjaan, sehingga selama UD. $\mathrm{X}$ memberi imbalan yang layak maka karyawan tidak memiliki alasan untuk meninggalkan pekerjaan mereka di UD. X.

Hasil uji hipotesis ketujuh menunjukkan bahwa motivasi karyawan memiliki pengaruh signifikan terhadap komitmen organisasional.

Hal ini sejalan dengan penelitian Pareke dan Suryana (2009); Jawad, Raja, dan Tabassum, 2012; dan Yazicioglu and Topaloglu (2009) yang juga menyatakan bahwa keadilan organisasional mempunyai pengaruh terhadap komitmen organisasional. Keadilan memang diberlakukan bagi semua karyawan, seperti adanya standarisasi pemberian gaji, perlakuan yang sama pemilik kepada semua karyawan, dan penerapan aturan dan instruksi bagi karyawan di perusahaan. Hal tersebut juga dikonfirmasi oleh beberapa karyawan, yang menyatakan hal yang sama. Adanya perlakuan yang adil pada setiap karyawan dianggap karyawan dapat menciptakan situasi kerja yang 
baik, sehingga karyawan merasa termotivasi bekerja di perusahaan.

Yazicioglu and Topaloglu (2009) mengatakan bahwa dengan adanya keadilan di dalam organisasi, maka karyawan akan merasa nyaman saat bekerja di perusahaan dan bekerja dengan senang hati; sehingga membuat karyawan semakin termotivasi. Hal ini membuat karyawan mempunyai rasa memiliki (sense of belonging), yang mempunyai hubungan erat dengan komitmen, seperti kebanggaan terhadap perusahaan dan keinginan bertahan dalam perusahaan (Davila \& Jimenez 2012). Teori yang dikemukakan oleh Gibson et al. (2012) juga mendukung hasil penelitian, karena beberapa dampak yang diberikan dari adanya keadilan organisasional adalah meningkatnya komitmen terhadap organisasi, meningkatnya kesetiaan karyawan terhadap organisasi, dan karyawan akan mempercayai atasannya.

\section{SIMPULAN}

Berdasarkan hasil penelitian yang dilakukan di UD. X, maka dapat diambil simpulan bahwa Keadilan Distributif dan Interaksional berpengaruh positif dan signifikan terhadap Motivasi Karyawan, sementara hanya Keadilan Distributif yang berpengaruh positif dan signifikan terhadap komitmen organisasional. Motivasi Karyawan terbukti mampu secara positif dan signifikan mempengaruhi Komitmen Organisasional. Temuan menarik justru muncul dari pengaruh negatif dan tidak signifikan dari Keadilan Prosedural terhadap Motivasi Karyawan, yang disebabkan oleh faktor demografi karyawan seperti tingkat pendidikan. Sementara walaupun Keadilan Prosedural dan Interaksional tidak memiliki pengaruh yang signifikan terhadap Komitmen Karyawan, namun kedua faktor tersebut memiliki arah pengaruh yang positif.

\section{DAFTAR PUSTAKA}

Adams, J. Stacy. 1963. Towards an understanding of inequity. The Journal of Abnormal and Social Psychology 67.5: 422.

Chao, C. C., Ya-Ru, C., \& Xin, K. 2004. Guanxi practices and trust in management: a procedural justice perspective. Organization Science. 15(2). 200-209.

Chen, Y., Friedman, R., Yu, E., \& Sun, F. 2011. Examining the positive and negative effects of guanxi practices: a multi-level analysis of guanxi practices and procedural justice perceptions. Asia Pacific Journal of Management. 28(4). 715-735.

Cobb, T.A., Folger, R. dan Wooten, K. 1995. The role justice plays in organizational change. Public Administration Quarterly, 9 (2): 135-147.

Davila, M. C., \& Jimenez, G. G. 2012. Organizational identification and commitment: Correlates of sense of belonging and affective commitment. US. PubMed.

Dessler, Gary, \& Tan Chwee Huat. 2009. Human Resources Management An Asian Perspective. 2nd Edition. Singapore. Prentice Hall.

Dysvik, Anders dan Bard Kuvaas. 2009. Exploring the relative and combined influence of mastery-approach goals and work intrinsic motivation on employee turnover intention. Personnel Review, 39, 622-638. www.emeraldinsight.com/00483486.htm.

Ghozali, I. 2012. Aplikasi Analisis Multivariate Dengan Program IBM SPSS. Semarang. Badan Penelitian Universitas Diponegoro.

Gibson, James. L., John. M. Ivancevich, James H. Donnelly, Jr., Robert Konopaske. 2009. Organizations Behavior, Structure, Processes 13th Edition. New York. McGrawHill.

Gibson, J. L., Donnelly, J. H., Ivancevich, J. M., \& Konopaske, R. 2012. Organizations: Behavior, Structure, Processes. Singapore. McGraw-Hill.

Greenberg, Jerald. 1987. A taxonomy of organizational justice theories. " Academy of Management Review 12.1: 9-22. 
Greenberg, Jerald. 1990. Organizational justice: yesterday, today, and tomorrow. "Journal of Management 16.2: 399432.

He, H., Zhu, W., \& Zheng, X. 2014. Procedural justice and employee engagement: roles of organizational identification and moral identity centrality. Journal of Business Ethics. 122(4). 681-695.

Ivancevich, John M. 2007. Human Resource Management. 10th Edition. New York:McGraw-Hill Companies.

Jawad, M., Raja, S., Abraiz, A., \& Tabassum, T. M. 2012. Role of organizational justice in or-ganizational commitment with moderating effect of employee work attitudes. IOSR Journal of Business and Management, 5(4), 39-45.

Jin, N. C. 2006. Multilevel and cross-level effects of workplace attitudes and group member relations on interpersonal helping behavior. Human Performance. 19(4). 383-402.

Karsli, Mehmet D., dan Hale Iskender. 2009. To examine the effect of the motivation provided by the administration on the job satisfaction of teachers and their institutional commitment. Procedia Social and Behavioral Sciences. 1, 2252-2257. www.elsevier.com.

Li, A., \& Cropanzano, R. 2009. Fairness at the group level: Justice climate and intraunit justice climate. Journal of Management. 35, 564 -599.

Loi, R., Lam, L., \& Chan, K. 2012. Coping with job insecurity: the role of procedural justice, ethical leadership and power distance orientation. Journal of Business Ethics. 108(3). 361-372.

Meyer, \& Allen .1997. Ignoring commitment is costly: New approaches establish the missing link bet-ween and performance. Human Relations, 50(6), 701726.

Noor, J. 2011. Metodologi penelitian. Jakarta. Kencana.
Noe, R.A., Hollenbeck, J.R., Gerhart, B., \& Wright, P.M. 2011. Manajemen Sumber Daya Manusia: Mencapai Keunggulan Bersaing, Edisi 6. Penerbit Salemba Empat.

Pareke, F. J., \& Suryana, P. 2009. Hubungan kausalitas antara keadilan organisasional, kepuasan kerja, \& komitmen organisasional. Trikonomika. 8(2), 96-102.

Robbins, Stephen P., \& Coulter, Mary. 2009. Management 9TH Edition. New Jersey:Pearson.

Robbins, Stephen P. \& Timothy A. Judge. 2008. Organizational Behavior. Prentice Hall.

Santoso, Singgih. 2009. Panduan Lengkap Menguasai Statistik dengan SPSS 17. Jakarta. PT Elex Media Komputindo.

Sia, S. K., Bhardwaj, G., \& Sahoo, B. C. 2013. Does nature of training, informal activitis and psychological contract impact fairness perception? Examining diverse group employees. Vision. 17(2). 129-142.

Sieger, Philipp, Fabian Bernhard, dan Urs Frey. 2011. Affective commitment and job satisfaction among non-family employees: Investigating the roles of justice perceptions and psychological ownership. Jornal of Family Business Strategy, 2, 78-89. www.elsevier.com/locate/jfbs.

Thibaut, John W. and Laurens Walker. 1975. Procedural Justice: A Psychological Analysis. L. Erlbaum Associates.

Vandenberg, Robert J., and Charles E. Lance. 1992. Examining the causal order of job satisfaction and organizational commitment. Journal of Management. 18.1: 153-167.

Williams Chuck. 2007. Management. 4th Edition. Texas. Thomson Higher Education.

Yazicioglu, I., \& Topaloglu, I. G. 2009. The relationship between organizational justice and commitment: A case study in accommodation establishments. 
Isletme Arastirmalan Dergisi, 1 (1), 3-16.

Zikmund, W. G., Babin, B. J., Carr, J. C., \& Griffin, M. 2010. Business Research
Method. Canada. South-Western Cengage Learning. 